\title{
Slaughter Indicators, Carcass Measures, and Meat Quality of Lamb Fattened with Spelt (Triticum aestivum spp. Spelta L.)
}

\author{
Josip Novoselec*(D), Željka Klir Šalavardić (D, Danijela Samac, Mario Ronta, Zvonimir Steiner, Vinko Sičaja and \\ Zvonko Antunović \\ Faculty of Agrobiotechnical Sciences Osijek, University of J.J. Strossamyer in Osijek, Trg Sv. Trojstva 3, \\ 31000 Osijek, Croatia; zklir@fazos.hr (Ž.K.Š.); dsamac@fazos.hr (D.S.); mronta@fazos.hr (M.R.); \\ zsteiner@fazos.hr (Z.S.); vinko-55@hotmail.com (V.S.); zantunovic@fazos.hr (Z.A.) \\ * Correspondence: jnovoselec@fazos.hr
}

check for updates

Citation: Novoselec, J.; Šalavardić, Ž.K.; Samac, D.; Ronta, M.; Steiner, Z.; Sičaja, V.; Antunović, Z. Slaughter Indicators, Carcass Measures, and Meat Quality of Lamb Fattened with Spelt (Triticum aestivum spp. Spelta L.) Foods 2021, 10, 726. https://doi.org/ 10.3390 /foods 10040726

Academic Editor:

Mohammed Gagaoua

Received: 19 February 2021

Accepted: 26 March 2021

Published: 30 March 2021

Publisher's Note: MDPI stays neutral with regard to jurisdictional claims in published maps and institutional affiliations.

Copyright: (c) 2021 by the authors. Licensee MDPI, Basel, Switzerland. This article is an open access article distributed under the terms and conditions of the Creative Commons Attribution (CC BY) license (https:// creativecommons.org/licenses/by/ $4.0 /)$.

\begin{abstract}
The aim of this research was to investigate the slaughter indicators, carcass measures, and meat quality of lambs fattened with spelt. Lambs consumed various feed mixtures $\left(1000 \mathrm{~g} \mathrm{day}^{-1}\right.$ $\mathrm{lamb}^{-1}$ ): I-control group; II-group with $10 \%$ dehulled spelt; III-group with $20 \%$ dehulled spelt. In the blood, the concentrations of minerals (calcium, phosphorus, magnesium, and iron), biochemical parameters (urea, glucose, total proteins, albumin, globulin, cholesterol, triglycerides, high-density lipoprotein, low-density lipoprotein, ß-hydroxybutyrate, non-esterified fatty acids, glutathione peroxidase, and superoxide dismutase), and hepatic enzymes (alanine aminotransferase, aspartate aminotransferase, alkaline phosphatase, gamma-glutamyltransferase, and creatine kinase) were determined. After slaughter, carcass development was measured. Samples of musculus semimembranosus were taken, of which the physical properties were analyzed. By analyzing the production properties of the lambs, we found that the slaughter characteristics of the lamb carcasses and the physical properties of the lamb meat as well as most biochemical indicators and enzymes did not significantly differ. The concentrations of albumin were increased in the groups with $10 \%$ and $20 \%$ spelt, as was the activity of alkaline phosphatase in the group with $20 \%$ spelt. The presented results indicate that spelt is an appropriate ingredient in the diet for weaned lambs.
\end{abstract}

Keywords: spelt; lamb; carcass measures; meat quality; biochemical parameters; enzyme

\section{Introduction}

Among the various production systems, in recent years, the organic production system has gained considerable importance, with the best prospects for even greater development in the future. In the last decade, the percentage of organic agricultural land has doubled [1]. Of the organic products, the most widespread are fruits and vegetables, and the least so is meat of organic origin [2], but with significant growth and development characteristics. According to [3], the production of organic meat over the last six years increased by $42.96 \%$, and that of organic lamb meat by $11.81 \%$. In the Republic of Croatia, there was a significant increase in the number of organically reared sheep in the period 2013-2019, from 19,411 to 65,632 (number of heads) [4]. Many studies have found that consumers buy organic food because they see it as healthier, and its production takes care of animal welfare and the environment $[2,5,6]$. Although there is no scientifically based evidence that organic food products are more nutritious than conventional ones [7], the fact that various organic livestock feed exclusively on green mass (pastures) and organic pesticide-free feeds has reduced their exposure to residues and antibiotic-resistant bacteria [7,8]. A significant problem in organic husbandry is ensuring an optimal ration in the winter feeding season, when animals fed dry feed must have a certain amount of concentrate composed of cereals of organic origin at their disposal. Organic cereal cultivation is more expensive than conventional cultivation because a large share of human labor is required and yields are lower. Given the above, spelt (Triticum aestivum spp. Spelta L.), due to its resistance (each 
grain has its hull) and, at the same time, modest or almost no requirements for fertilization and care, is suitable for organic farming and is an adequate replacement for conventional cereals used in the feeding of sheep and lambs [9]. Spelt has limited use as fodder due to the hull on the grain, but after dehulling, it is widely used as an ingredient in feed mixtures and in the bakery industry [10]. Spelt does not tolerate mineral fertilizers because it settles down, and it is then impossible to harvest them with a combine harvester; it also has a reduced content of gluten and a high content of fiber, which contributes to its easier and better digestion. The nutritional value of spelt is similar to the nutritional value of wheat and contains most nutrients needed in human and animal nutrition such as proteins, unsaturated fatty acids, vitamins (A, C, and B groups), minerals (calcium, cobalt, iron, phosphorus, magnesium, manganese, potassium, copper, selenium, and sodium), and fiber [11-13]. Due to selenium (a part of the enzyme superoxide dismutase that catalyzes the dismutation of superoxide into oxygen and hydrogen peroxide), spelt can have a positive influence on antioxidant protection [14] in the defense of almost all cells exposed to aerobic metabolism. In the available literature, there is no research on fattening lambs with spelt. Therefore, the present research aimed to investigate blood indicators of nutritional and health status, slaughter indicators, carcass measures, and meat quality of lamb fattened with spelt (Triticum aestivum spp. Spelta L.) and to determine whether spelt is suitable as an ingredient in the feed mixture of lambs.

\section{Materials and Methods}

\subsection{Design of Experiment and Treatments}

The research was conducted on an organic family farm in the village of Gašinci, OsijekBaranja County, Croatia $\left(45^{\circ} 20^{\prime} 05^{\prime \prime} \mathrm{N}, 18^{\circ} 18^{\prime} 59^{\prime \prime} \mathrm{E}\right)$, which raises Merinolandschaf sheep exclusively for the production of lamb. The research was conducted with 21 weaned lambs, Merinolandschaf breed, at an average age of 95 days. The lambs were divided by gender (3 females; 4 males) in each group and had good health:
I. Control group;
II. Group with $10 \%$ dehulled spelt;
III. Group with $20 \%$ dehulled spelt.

Lambs consumed hay and water ad libitum. The ingredients and chemical compositions of the feed mixtures are shown in Table 1. The lambs consumed a feed mixture $\left(1000 \mathrm{~g} \mathrm{day}^{-1}\right)$ made of organic feedstuffs origin. In the production of the mentioned feed mixtures for lambs, a mineral premix was used (Panto Mineral) which is certified for use in organic sheep and lamb rearing. For determination of the crude protein content in feed samples, the Kjeldahl method was used [15]. The Weende method [16] was used for determination of the crude fiber content in feed samples. The lambs were reared and fed according to Council Regulation (EC) no. 834/2007 on organic production [17]. Animals used in this study were maintained in facilities approved by the Croatian Association for Accreditation of Laboratory Animal Care and in accordance with current regulations and standards issued by the Croatian Ministry of Agriculture. Each group of lambs was kept separately with no access to pasture. The experiment lasted for a total of 30 days; animals were weighed every 15 days - at the beginning of the experiment (1 day), in the middle (15 days), and at the end (30 days). 
Table 1. Ingredients and proximate analysis of feed mixtures and meadow hay.

\begin{tabular}{|c|c|c|c|c|}
\hline \multirow{2}{*}{ Component (\%) } & \multicolumn{3}{|c|}{ Group } & \multirow{2}{*}{ Hay } \\
\hline & I & II & III & \\
\hline Corn & 39 & 39 & 39 & \\
\hline Oats & 10 & 5 & 0 & \\
\hline Barley & 15 & 10 & 5 & \\
\hline Wheat flour & 15 & 15 & 15 & \\
\hline Soybean meal girts & 18 & 18 & 18 & \\
\hline Spelt & 0 & 10 & 20 & \\
\hline Mineral premix * & 3 & 3 & 3 & \\
\hline \multicolumn{5}{|c|}{ Chemical composition ( $\left.\mathrm{g} \mathrm{kg}^{-1} \mathrm{DM}\right)$} \\
\hline Dry matter & 891.5 & 890.0 & 891.4 & 862.5 \\
\hline Crude protein & 157.2 & 160.1 & 159.05 & 141.5 \\
\hline Crude fat & 25.3 & 24.5 & 21.3 & 12 \\
\hline Crude fiber & 45.6 & 45.6 & 36.1 & 255.2 \\
\hline Ash & 58.35 & 57.05 & 59.5 & 83.0 \\
\hline NEM MJ kg ${ }^{-1}$ & 736.4 & 736.6 & 736.88 & 2.26 \\
\hline
\end{tabular}

I-control group; II-10\% dehulled spelt; III-20\% dehulled spelt; * $1 \mathrm{~kg}$ of premix contains VIT. A = 1,000,000 IJ VIT. D3 = 150,000 IJ; VIT. E = 1500 mg; VIT. K3 = 50 mg; VIT. B1 = $100 \mathrm{mg}$; VIT. B2 = $200 \mathrm{mg}$; VIT. B6 = 200 mg; VIT. $\mathrm{B} 12=1 \mathrm{mg} ;$ Ca pantotenat $=500 \mathrm{mg} ;$ Niacin $=1000 \mathrm{mg} ;$ Choline chloride $=20,000 \mathrm{mg} ; \mathrm{FeSO}_{4}=4000 \mathrm{mg} ; \mathrm{CuSO}_{4}=$ $800 \mathrm{mg}$; Mn-oxide $=3500 \mathrm{mg}$; Zn-sulphate $=5000 \mathrm{mg}$; Cobalt chloride $=20 \mathrm{mg}$; Mg-sulphate = 10,000 mg; Antiox. dibutylhydroxytoluene $(\mathrm{BHT})=10,000 \mathrm{mg} ; 10,000 \mathrm{mg}$; Potassium iodide $=80 \mathrm{mg}$.

\subsection{Collection and Analysis of Blood Samples}

Lamb blood samples were collected at the same time when they were weighted $(1,15$, and 30 days) from the jugular vein $(10 \mathrm{~mL})$ into sterile vacuum tubes $\left(\right.$ Venoject ${ }^{\circledR}$, Sterile Terumo Europe, Leuven, Belgium). After taking the blood samples, serum was separated by centrifugation (10 $\mathrm{min}$ ) at $1609.92 \times g$ and analyzed in an Olympus AU640 analyzer. In the blood serum, mineral concentrations (calcium-Ca; inorganic phosphorus- $\mathrm{P}$; ironFe; magnesium- $\mathrm{Mg}$ ), biochemical parameters (urea, glucose, total proteins, cholesterol, albumin, globulin, triglyceride, high-density lipoprotein (HDL), low-density lipoprotein (LDL), hydroxybutyrate (BHB), non-esterified fatty acids (NEFAs), glutathione peroxidase (GPX), and superoxide dismutase (SOD)), and hepatic enzyme activity (alanine aminotransferase-ALT; aspartate aminotransferase-AST; alkaline phosphatase-ALP; gamma-glutamyltransferase-GGT; creatine kinase-CK) were all determined using Olympus System Reagents (OSR), manufactured and distributed by Olympus Diagnostica GmbH (Irish branch), Lismeehan, Ireland. Content of globulin was determined as the difference between total protein and albumin.

\subsection{Slaughter and Carcass Evaluation}

Before slaughter, lambs were weighed on an automatic animal scale Kern EOS 150K50XL (Kern and Sohn, Balingen, Germany). After slaughter (classical method of bleeding by cutting large blood vessels in the neck-vena jugularis externa and arteria carotis communis) and exsanguination, the lambs' skin was peeled off the carcasses, and abdominal (forestomach, stomach, spleen, intestine, and liver) and thoracic (trachea with the lungs and heart) cavity organs were then detached. All internal organs, skin, lower parts of the legs, and the carcasses themselves were weighed. Finally, standard development measurements (linear measure) of lamb carcasses were taken: the length of the carcass (carcass length 1 -os pubis to atlas; carcass length 2-os pubis to first rib; carcass length 3-os pubis to last rib), the circumference of the carcass at chest and ham, the length of the hind legs (tuber calcanei to tubercle ossis ischia), and the hind leg circumference (the widest part).

\subsection{Meat Quality Evaluation}

Lamb meat samples (musculus semimembranosus) were taken from all the lambs immediately after carcass processing, while $\mathrm{pH}$ values and color were determined $45 \mathrm{~min}$ 
post-mortem. The $\mathrm{pH}$ was measured with a Mettler Toledo contact $\mathrm{pH}$ meter using the spear-tip penetrating probe electrode method, while the color of the meat was measured with a Minolta Chroma Meter CR-410 portable instrument (Minolta Camera Co. Ltd., Osaka, Japan) according to the standard CIE L*a*b* color system [18]. Dressing percentage was calculated as (weight before slaughter-carcass weight $\times 100$ ). Water-holding capacity was measured by the method of [19]. Hue angle was calculated according to the formula $\mathrm{H}^{*}=\tan ^{-1}\left(\mathrm{~b}^{*} / \mathrm{a}^{*}\right) \times(180 / \pi)$, and chroma using the formula $\mathrm{C}^{*}=\sqrt{ }\left(\mathrm{a}^{* 2}+\mathrm{b}^{* 2}\right)$.

\subsection{Statistical Analysis}

Mean values of the obtained research results of production and slaughter indicators as well as carcass development indicators and physical properties were calculated by the MEANS procedure in the computer program TIBCO Statistica ${ }^{\circledR}$ 13.3.0. Data were analyzed by means of an ANOVA, using feeding treatment as a fixed effect. Mean values were compared using Tukey's test and differences between the groups were declared significant at $p<0.05$ or less. Effects of treatment (I-control group; II-group with $10 \%$ dehulled spelt; III -group with $20 \%$ dehulled spelt) times (age) as repetitions and their interaction in the experimental period on production results and blood biochemical indicators were analyzed using GLM repeated measures ANOVA. Where the analysis showed significant differences, the LSD post hoc test was performed.

\section{Results and Discussion}

From the analysis of the production traits and slaughter indicators of lambs (Tables 2 and 3), it is visible that there were no significant differences $(p>0.05)$ under varying nutrition influences.

Table 2. Production traits of lambs.

\begin{tabular}{|c|c|c|c|c|c|c|c|c|}
\hline \multirow{3}{*}{ Indicator } & \multirow{3}{*}{$\begin{array}{l}\text { Age, } \\
\text { Days }\end{array}$} & \multicolumn{3}{|c|}{ Group } & \multirow{3}{*}{ SEM } & \multicolumn{3}{|c|}{$p$-Value } \\
\hline & & I & II & III & & \multirow{2}{*}{ Group } & \multirow{2}{*}{ Age } & \multirow{2}{*}{ A. $\times$ G } \\
\hline & & Mean & Mean & Mean & & & & \\
\hline \multirow{4}{*}{ Body weight $[\mathrm{kg}]$} & 95 & 28.76 & 28.63 & 28.77 & 0.36 & \multirow{4}{*}{0.932} & \multirow{4}{*}{$<0.01$} & \multirow{4}{*}{0.912} \\
\hline & 110 & 32.80 & 32.57 & 32.63 & 0.50 & & & \\
\hline & 125 & 35.89 & 34.92 & 34.99 & 0.72 & & & \\
\hline & \multicolumn{5}{|c|}{ Daily weight gain, $g$} & & & \\
\hline \multicolumn{2}{|c|}{ Average (1st-15th day) } & 269.71 & 262.67 & 257.14 & 26.11 & \multirow{3}{*}{0.790} & \multirow{3}{*}{$<0.01$} & \multirow{3}{*}{0.891} \\
\hline \multicolumn{2}{|c|}{ Average (15th-30th day) } & 205.71 & 156.76 & 157.14 & 18.65 & & & \\
\hline Average (1st-30 & & 237.71 & 209.71 & 207.14 & 19.26 & & & \\
\hline \multicolumn{2}{|c|}{ Feed conversion, g DM/g gain, $(1-30)$} & 4.40 & 4.97 & 4.99 & - & - & - & - \\
\hline
\end{tabular}

Mean-arithmetic mean; SEM—standard error of mean; A.—age; G.-group; I—control group; II-10\% dehulled spelt; III-20\% dehulled spelt.

Table 3. Slaughter indicators of lambs.

\begin{tabular}{|c|c|c|c|c|c|}
\hline \multirow{3}{*}{ Indicators, kg } & \multicolumn{3}{|c|}{ Group } & \multirow{3}{*}{ SEM } & \multirow{3}{*}{$p$-Value } \\
\hline & I & II & III & & \\
\hline & Mean \pm sd & Mean \pm sd & Mean \pm sd & & \\
\hline Live weight at slaughter & $35.89 \pm 3.18$ & $34.81 \pm 4.42$ & $34.67 \pm 2.58$ & 0.731 & 0776 \\
\hline Hot carcass weight & $19.27 \pm 1.75$ & $19.53 \pm 2.10$ & $19.05 \pm 0.97$ & 0.349 & 0.864 \\
\hline Dressing percentage, $\%$ & $53.52 \pm 1.39$ & $56.25 \pm 2.14$ & $55.05 \pm 2.48$ & 0.484 & 0.096 \\
\hline Organs * & $1.79 \pm 0.48$ & $1.54 \pm 0.28$ & $1.63 \pm 0.26$ & 0.077 & 0.417 \\
\hline Forestomach and intestines & $7.92 \pm 0.80$ & $6.74 \pm 1.11$ & $6.97 \pm 1.07$ & 0.237 & 0.092 \\
\hline Skin and lower legs & $4.99 \pm 0.38$ & $5.04 \pm 0.86$ & $4.94 \pm 0.47$ & 0.126 & 0.952 \\
\hline
\end{tabular}

Mean-arithmetic mean; sd-standard deviation; SEM-standard error of the mean; ${ }^{*}$ lungs, trachea, heart, and liver; I-control group; II-10\% dehulled spelt; III-20\% dehulled spelt.

Similar results in organic breeding of lambs in Italy and Croatia, with no significant differences in production traits as well as slaughter indicators (Tables 2 and 3), were determined in the feeding of lambs with feed mixture in which peas were used as a 
source of protein instead of soybean meal [20,21]. A slightly lower dressing percentage in Merinolandschaf lambs compared to the present research has determined [22]. The higher dressing percentage of lambs established in the present research may be due to the lower live body weight of the lambs compared to the abovementioned Merinolandschaf lambs, which is confirmed by the results of the research [23].

The study [24] which investigated the effect of the incorporation of spelt in the concentrate on calf performance reported no effect on daily weight gain $(p=0.970)$. Furthermore, the authors concluded that spelt can stimulate concentrate intake, but no major effect on animal performance during the entire rearing period was noted. The authors showed a higher spelt concentrate intake by Holstein-Friesian calves during several weeks after weaning, but not in Belgian Blue double-muscled calves because of their limited intake capacity. Spelt has a lower energy content then wheat and barley; it is assumed that spelt is less able to fulfill energy requirements because of the lower energy density of spelt concentrate. This result is in accordance with the previous findings of [25], indicating that lambs avoid diets with a deficit or an excess of energy compared to lamb feed with a more adequate ration. In a 90-day trial in which an equal weight of spelt replaced oats or corn and was fed as a growth supplement to diary heifers, those fed oats or spelt exhibited similar live weight increases, while those fed corn had greater $(p<0.05)$ gains [26].

Feeding treatment did not significantly influence $(p>0.05)$ the carcass development and physical properties of the lamb carcasses and meat (Tables 4 and 5). The measures of lamb carcass development of the processed carcasses of the studied lambs are comparable with the results of the research in [22] on the same breed of lambs. A higher water-holding capacity (WHC) was established in the meat of lambs that had consumed feed mixture with spelt, but differences were not significant $(p=0.824)$. The content of water in meat products is one of the most important quality parameters for meat processors as it relates to the final yield [27] of the final product and is also important in terms of eating. Water-holding capacity has a great impact on quality attributes such as juiciness and tenderness [28-30], and, if extreme, weakens the sensory perception of the meat. A number of intrinsic and extrinsic factors affect the WHC of meat. The most important intrinsic factors are genotype and feeding of animals, which affect muscle characteristics directly [31]. According to [32], to control extreme water loss during processing, it is largely accepted that $\mathrm{pH}$ is a crucial factor for controlling the ability of meat to hold water. Similar WHC and $\mathrm{pH}$ values in lamb meat to those in the present research were established [21] in organic breeding where lambs consumed feed mixture with the addition of peas.

Table 4. Measures of lamb carcass development.

\begin{tabular}{|c|c|c|c|c|c|}
\hline \multirow{3}{*}{ Indicators, $\mathrm{cm}$} & \multicolumn{3}{|c|}{ Group } & \multirow{3}{*}{ SEM } & \multirow{3}{*}{$p$-Value } \\
\hline & I & II & III & & \\
\hline & Mean \pm sd & Mean \pm sd & Mean \pm sd & & \\
\hline Carcass length $^{1}$ & $76.00 \pm 2.58$ & $75.14 \pm 2.73$ & $73.79 \pm 3.51$ & 0.647 & 0.391 \\
\hline Carcass length ${ }^{2}$ & $55.71 \pm 1.91$ & $52.36 \pm 4.31$ & $52.79 \pm 4.57$ & 0.852 & 0.224 \\
\hline Carcass length ${ }^{3}$ & $28.29 \pm 2.12$ & $29.35 \pm 1.95$ & $29.93 \pm 2.82$ & 0.505 & 0.424 \\
\hline Carcass circumference at chest & $68.21 \pm 2.41$ & $68.21 \pm 1.97$ & $69.07 \pm 1.33$ & 0.406 & 0.634 \\
\hline Carcass circumference at ham & $54.14 \pm 2.98$ & $54.79 \pm 2.98$ & $55.64 \pm 2.43$ & 0.597 & 0.613 \\
\hline Hind leg circumference & $34.64 \pm 3.70$ & $33.21 \pm 2.12$ & $34.29 \pm 4.81$ & 0.726 & 0.726 \\
\hline Hind leg length & $31.14 \pm 1.38$ & $32.00 \pm 1.50$ & $31.21 \pm 1.58$ & 0.319 & 0.501 \\
\hline
\end{tabular}

Mean-arithmetic mean; sd—standard deviation; SEM-standard error of the mean; ${ }^{1}$ carcass length (pubis-atlas axis); ${ }^{2}$ carcass length (pubis axis-first rib); ${ }^{3}$ carcass length (pubis axis-posterior rib); I—control group; II-10\% dehulled spelt; III-20\% dehulled spelt. 
Table 5. Physical properties of lamb meat.

\begin{tabular}{|c|c|c|c|c|c|}
\hline \multirow{3}{*}{ Indicators } & \multicolumn{3}{|c|}{ Group } & \multirow{3}{*}{ SEM } & \multirow{3}{*}{$p$-Value } \\
\hline & I & II & III & & \\
\hline & Mean \pm sd & Mean \pm sd & Mean \pm sd & & \\
\hline $\mathrm{pH}_{1}$ & $6.59 \pm 0.31$ & $6.58 \pm 0.17$ & $6.59 \pm 0.18$ & 0.047 & 0.992 \\
\hline WHC (\%) & $18.38 \pm 5.39$ & $20.05 \pm 4.67$ & $20.05 \pm 6.97$ & 1.205 & 0.824 \\
\hline \multicolumn{6}{|c|}{ Meat Color } \\
\hline Lightness & $35.58 \pm 1.35$ & $35.33 \pm 1.74$ & $34.92 \pm 2.23$ & 0.379 & 0.787 \\
\hline Redness & $15.15 \pm 0.92$ & $14.63 \pm 1.05$ & $14.22 \pm 0.81$ & 0.211 & 0.198 \\
\hline Yellowness & $0.55 \pm 0.63$ & $0.85 \pm 0.59$ & $0.61 \pm 0.42$ & 0.118 & 0.568 \\
\hline Hue angle & $2.05 \pm 2.29$ & $3.22 \pm 2.09$ & $2.42 \pm 1.59$ & 0.432 & 0.551 \\
\hline Chroma & $15.17 \pm 0.92$ & $14.66 \pm 1.08$ & $14.24 \pm 0.82$ & 0.214 & 0.208 \\
\hline
\end{tabular}

Mean-arithmetic mean; sd-standard deviation; SEM—standard error of the mean; WHC-Water-holding capacity; I—control group; II—10\% dehulled spelt; III—20\% dehulled spelt.

Meat from suckling lambs is paler than that from weaned lambs because of the low concentration of iron in ewe milk [33]. The color of lamb meat is crucial to ensuring customer appeal and strongly contributes to the value of the product. According to [34] and [35], for fresh lamb meat, when the redness $\left(a^{*}\right)$ and lightness $\left(L^{*}\right)$ values are equal to or exceed 9.5 and 34, respectively, on average, consumers will consider the meat color acceptable, which agrees with results of present study. The acceptability thresholds derived by [34] for lamb equated to a chromameter $L^{*}$ value of 34-35 and a redness $\left(a^{*}\right)$ value below 19. Similar findings of meat color indicators were reported, with no statistical difference among nutritional treatments determined [21,22]. Lamb carcass characteristics and meat quality parameters (such as $\mathrm{pH}$, meat color, water-holding capacity, and meat toughness) are consequences and results of the feeding system [36,37]. Meat from grazing animals has often been associated with yellow fat [38,39] and dark, tough, and little-flavored meat [37].

The lambs' blood biochemical and mineral (Tables 6 and 7) indicators were in the reference range in all three groups [40-42], which indicates the quality of their nutrition, which is also shown in the determined production traits and slaughter indicators (Tables 2 and 3). Results comparable with the present research have previously been obtained [21]. In the present research, with progress of the trial, the values of some indicators $(\mathrm{Fe}$, urea, HDL, and LDL) approached the reference values. The increase in AST up to 120 days of age resulted from the combination of an increase in mass and muscle activity and an improvement in the endogenous production of this enzyme with the development of the animal [43-45]. Creatine kinase is a muscle-specific enzyme characterized as a very sensitive bioindicator of the degree of activity, damage, and/or muscular effort $[46,47]$. According to [48], CK has high intramuscular activity and sensitivity and might vary quickly after minimal damage. Instability of this enzyme even in the face of common activities of routine management, such as restraint and weighing of animals, or as a result of intramuscular injections, exercise, or physical effort has been reported [40]. Therefore, it is possible that the variations in the present study might have occurred due to subtle differences in movement and the blood collection. Increased activities of ALP in the blood plasma of all lambs, regardless of dietary treatment, was observed in [49]. The authors claimed that high values of this enzyme are considered to be physiologically normal in growing animals, which agrees with the present research. High values of ALP are probably due to a fast growth rate that results in leakage of the enzyme from the growing bones and intestines into the blood [50]. Glucose levels were slightly higher compared to the reference values. According to [51], glycemia in ruminants is not influenced much by feeding, since it is regulated by an efficient hormonal homeostatic mechanism that aims to keep its concentration constant. Despite the performance of this mechanism, in the neonatal period and during the growth phase, glycemia is greatly influenced by age $[44,45]$ and is related to the intake of colostrum and milk, as well as to the maturation of the liver, pancreas, and enzymatic activities and to the adaptation of the organism to 
the extrauterine environment [52]. The cholesterol concentrations were somewhat lower compared to the reference values in all groups during the entire trial. Research $[53,54]$ has shown that the type of dietary protein, especially lysine-to-arginine ratio and the sulfur-containing amino acids (methionine and cysteine), has been considered a factor influencing the cholesterol serum concentration in rabbits. As verified among the animals evaluated in the studies by $[45,55]$, a decrease in total cholesterol concentrations with advancing age was shown as a consequence of the modifications to the diet during the first months of life. The concentrations of the total proteins and globulin (Table 7) in the blood of the lambs increased with advanced age. As the age increases, the concentration of total protein in the blood of sheep increases $[47,56]$. The high total protein content after birth can be a result of serum immunoglobulin content growth, and this demonstrates good alimentary canal absorption and has some effect on later clinical state [57]. Albumin concentrations also affect the total protein levels. Albumin is the main plasma protein synthesized by the liver and corresponds to approximately $35-50 \%$ of total serum proteins and is responsible for $80 \%$ of the colloid osmotic pressure [41]. Albumin concentration is influenced by dietary protein intake and is considered the most sensitive indicator for the determination of protein nutritional status in the long term, since changes in its concentrations are detected only after a minimum period of one month due to its low rate of synthesis and degradation [58]. The cholesterol concentration is influenced by the degree of stress [59]. Therefore, lower cholesterol with age might be expected from stress (particularly by weaning lambs).

Table 6. Blood enzyme indicators in lambs.

\begin{tabular}{|c|c|c|c|c|c|c|c|c|}
\hline \multirow{3}{*}{$\begin{array}{l}\text { Indicators, } \\
\mathrm{UL}^{-1}\end{array}$} & \multirow{3}{*}{$\begin{array}{l}\text { Age } \\
\text { Days }\end{array}$} & \multicolumn{3}{|c|}{ Group } & \multirow{3}{*}{ SEM } & \multirow{2}{*}{\multicolumn{3}{|c|}{$p$-Value }} \\
\hline & & I & II & III & & & & \\
\hline & & Mean & Mean & Mean & & Group & Age & G. $\times$ A. \\
\hline \multirow{3}{*}{ AST } & 90 & 107.13 & 112.99 & 113.29 & 5.55 & \multirow{3}{*}{0.834} & \multirow{3}{*}{0.374} & \multirow{3}{*}{0.993} \\
\hline & 105 & 101.80 & 102.99 & 100.59 & 3.64 & & & \\
\hline & 120 & 110.11 & 110.90 & 115.03 & 5.35 & & & \\
\hline \multirow{3}{*}{ ALT } & 90 & 12.60 & 12.72 & 13.90 & 0.82 & \multirow{3}{*}{0.793} & \multirow{3}{*}{0.897} & \multirow{3}{*}{0.898} \\
\hline & 105 & 13.41 & 14.10 & 12.96 & 0.82 & & & \\
\hline & 120 & 12.57 & 14.59 & 13.89 & 0.73 & & & \\
\hline \multirow{3}{*}{ ALP } & 90 & 187.33 & 168.41 & 244.87 & 14.37 & \multirow{3}{*}{$<0.001$} & \multirow{3}{*}{$<0.001$} & \multirow{3}{*}{0.816} \\
\hline & 105 & $333.07^{a}$ & $331.64^{\mathrm{a}}$ & $482.40^{b}$ & 26.22 & & & \\
\hline & 120 & 315.36 & 315.34 & 429.61 & 27.36 & & & \\
\hline \multirow{3}{*}{ GGT } & 90 & 59.27 & 73.00 & 64.11 & 4.15 & \multirow{3}{*}{0.553} & \multirow{3}{*}{0.476} & \multirow{3}{*}{0.538} \\
\hline & 105 & 64.54 & 67.64 & 70.19 & 3.25 & & & \\
\hline & 120 & 59.09 & 61.70 & 67.47 & 2.76 & & & \\
\hline \multirow{3}{*}{ CK } & 90 & 213.14 & 187.14 & 244.00 & 14.28 & \multirow{3}{*}{0.308} & \multirow{3}{*}{$<0.001$} & \multirow{3}{*}{0.490} \\
\hline & 105 & 137.14 & 167.14 & 176.57 & 13.49 & & & \\
\hline & 120 & 121.71 & 141.57 & 134.14 & 7.35 & & & \\
\hline
\end{tabular}

Mean-arithmetic mean; SEM-standard error of the mean; G.—group; A.—age; I—control group; II—10\% dehulled spelt; III—20\% dehulled spelt; ${ }^{\mathrm{a}, \mathrm{b}}(p<0.05)$; AST—aspartate aminotransferase; ALT—alanine aminotransferase; ALP—alkaline phosphatase; GGT—gamma-glutamyltransferase; CK—creatine kinase. 
Table 7. Blood biochemical indicators in lambs.

\begin{tabular}{|c|c|c|c|c|c|c|c|c|}
\hline \multirow{3}{*}{$\begin{array}{l}\text { Indicators, } \\
\text { Mmol L L }^{-1}\end{array}$} & \multirow{3}{*}{$\begin{array}{l}\text { Age } \\
\text { Days }\end{array}$} & \multicolumn{3}{|c|}{ Group } & \multirow{3}{*}{ SEM } & \multirow{2}{*}{\multicolumn{3}{|c|}{$p$-Value }} \\
\hline & & \multirow{2}{*}{$\begin{array}{c}\text { I } \\
\text { Mean }\end{array}$} & \multirow{2}{*}{$\begin{array}{c}\text { II } \\
\text { Mean }\end{array}$} & \multirow{2}{*}{$\begin{array}{c}\text { III } \\
\text { Mean }\end{array}$} & & & & \\
\hline & & & & & & Group & Age & Gr. $\times \mathbf{A}$. \\
\hline \multirow{3}{*}{$\mathrm{Mg}$} & 90 & 0.91 & 0.88 & 1.01 & 0.04 & \multirow{3}{*}{0.234} & \multirow{3}{*}{$<0.001$} & \multirow{3}{*}{0.947} \\
\hline & 105 & 1.15 & 1.17 & 1.29 & 0.05 & & & \\
\hline & 120 & 1.13 & 1.22 & 1.27 & 0.04 & & & \\
\hline \multirow{3}{*}{$\mathrm{Fe}, \mu \mathrm{mol} / \mathrm{L}$} & 90 & 19.60 & 25.70 & 25.39 & 2.06 & \multirow{3}{*}{0.133} & \multirow{3}{*}{0.011} & \\
\hline & 105 & 25.11 & 33.06 & 30.91 & 1.99 & & & 0.902 \\
\hline & 120 & 30.99 & 32.93 & 32.17 & 1.63 & & & \\
\hline & 90 & 2.61 & 2.37 & 2.59 & 0.10 & & & \\
\hline $\mathrm{P}$ & 105 & 3.19 & 3.38 & 3.23 & 0.08 & 0.806 & 0.001 & 0.421 \\
\hline & 120 & 2.99 & 2.78 & 2.72 & 0.07 & & & \\
\hline & 90 & 2.42 & 2.41 & 2.36 & 0.03 & & & \\
\hline $\mathrm{Ca}$ & 105 & 2.57 & 2.59 & 2.64 & 0.03 & 0.621 & $<0.001$ & 0.542 \\
\hline & 120 & 2.61 & 2.53 & 2.63 & 0.02 & & & \\
\hline & 90 & 5.21 & 5.39 & 5.53 & 0.07 & & & \\
\hline GUK & 105 & 5.50 & 5.75 & 5.84 & 0.11 & 0.099 & 0.047 & 0.668 \\
\hline & 120 & 5.42 & 5.18 & 5.54 & 0.09 & & & \\
\hline & 90 & 2.12 & 1.83 & 1.71 & 0.24 & & & \\
\hline Urea & 105 & 6.79 & 7.98 & 6.98 & 0.22 & 0.699 & $<0.001$ & 0.016 \\
\hline & 120 & 6.74 & 6.19 & 7.85 & 0.28 & & & \\
\hline & 90 & 64.94 & 65.19 & 62.53 & 1.07 & & & \\
\hline PROT, $\mathrm{gL}^{-1}$ & 105 & 70.86 & 69.11 & 68.21 & 1.18 & 0.581 & $<0.001$ & 0.869 \\
\hline & 120 & 69.91 & 70.37 & 70.47 & 0.86 & & & \\
\hline & 90 & 27.10 & 29.11 & 29.25 & 0.52 & & & \\
\hline $\mathrm{ALB}, \mathrm{gL}^{-1}$ & 105 & 29.60 & 30.86 & 30.72 & 0.39 & 0.048 & $<0.001$ & 0.925 \\
\hline & 120 & $30.11^{\mathrm{a}}$ & $31.64^{b}$ & $31.90^{\mathrm{b}}$ & 0.32 & & & \\
\hline & 90 & 37.84 & 36.07 & 33.26 & 1.09 & & & \\
\hline GLOB, $\mathrm{gL}^{-1}$ & 105 & 41.25 & 38.26 & 37.45 & 1.12 & 0.166 & 0.036 & 0.855 \\
\hline & 120 & 39.80 & 38.73 & 38.57 & 0.92 & & & \\
\hline & 90 & 1.79 & 1.72 & 1.71 & 0.09 & & & \\
\hline CHOL & 105 & 1.28 & 1.29 & 1.14 & 0.04 & 0.390 & $<0.001$ & 0.976 \\
\hline & 120 & 1.34 & 1.28 & 1.23 & 0.04 & & & \\
\hline & 90 & 0.42 & 0.29 & 0.34 & 0.02 & & & \\
\hline TGC & 105 & 0.30 & 0.26 & 0.27 & 0.02 & 0.094 & 0.001 & 0.575 \\
\hline & 120 & 0.29 & 0.25 & 0.26 & 0.02 & & & \\
\hline & 90 & 1.16 & 1.07 & 1.12 & 0.05 & & & \\
\hline HDL & 105 & 0.82 & 0.96 & 0.75 & 0.05 & 0.337 & $<0.001$ & 0.523 \\
\hline & 120 & 0.86 & 0.80 & 0.82 & 0.02 & & & \\
\hline & 90 & 0.44 & 0.52 & 0.44 & 0.04 & & & \\
\hline LDL & 105 & 0.32 & 0.35 & 0.27 & 0.02 & 0.303 & 0.004 & 0.985 \\
\hline & 120 & 0.35 & 0.37 & 0.30 & 0.03 & & & \\
\hline & 90 & 0.36 & 0.22 & 0.13 & 0.08 & & & \\
\hline NEFA & 105 & 0.11 & 0.03 & 0.03 & 0.02 & 0.538 & 0.005 & 0.691 \\
\hline & 120 & 0.00 & 0.03 & 0.01 & 0.003 & & & \\
\hline & 90 & 0.32 & 0.23 & 0.25 & 0.025 & & & \\
\hline BHB & 105 & 0.25 & 0.30 & 0.26 & 0.017 & 0.125 & 0.612 & 0.399 \\
\hline & 120 & 0.28 & 0.20 & 0.24 & 0.019 & & & \\
\hline & 90 & 336.09 & 298.07 & 332.74 & 26.19 & & & \\
\hline GPX & 105 & 250.03 & 284.89 & 266.86 & 19.19 & 0.979 & 0.260 & 0.886 \\
\hline & 120 & 298.32 & 320.22 & 290.70 & 20.53 & & & \\
\hline & 90 & 0.33 & 0.23 & 0.32 & 0.03 & & & \\
\hline SOD & 105 & 0.34 & 0.31 & 0.41 & 0.02 & 0.365 & 0.046 & 0.609 \\
\hline & 120 & 0.36 & 0.42 & 0.43 & 0.04 & & & \\
\hline
\end{tabular}

Mean-arithmetic mean; sd—standard deviation; SEM—standard error of the mean; I—control group; II—10\% dehulled spelt; III-20\% dehulled spelt; ${ }^{\mathrm{a}, \mathrm{b}}(p<0.05)$; Mg—magnesium; Fe-iron; P—inorganic, phosphorus; $\mathrm{Ca}$-calcium; GUK-glucose; PROT—total proteins; ALB—albumin; GLOB-globulin; CHOL-cholesterol; TGC—triglyceride; HDL—high-density lipoprotein; LDL—low-density lipoprotein; BHB-hydroxybutyrate; NEFA—non-esterified fatty acid; GPX—glutathione peroxidase; SOD—superoxide dismutase. 
The significant decrease in triglycerides with aging might have been caused by changes in feeding management, as well as by the improvement in hepatic maturation and the ability to metabolize lipids [60]. Spelt did not significantly $(p>0.05)$ affect the activity of the enzymes SOD and GPX, thus not affecting the antioxidant activity of lamb's blood, but a trend of higher values is present in the lambs fed with spelt. NEFA reflects the magnitude of fat mobilization from fat stores in response to negative energy balance. In the present study, NEFA levels (ranged from 0.00 to $0.36 \mathrm{mmol} \mathrm{L}^{-1}$ ) during the whole trial were consistent with normal levels (NEFA, $<0.45 \mathrm{mmol} \mathrm{L}^{-1}$ ) described by [41]. Lower NEFA values indicate that there is less fat mobilization in these animals. BHB concentration may be a useful indicator in monitoring the energy status of lambs. In the present study, the $\mathrm{BHB}$ concentrations ranged from 0.20 to $0.32 \mathrm{mmol} \mathrm{L}^{-1}$ (normal level of BHB: 0.2 to $0.7 \mathrm{mmol} \mathrm{L}^{-1}$ according to [41]). Values of BHB from 0.80 to $1.60 \mathrm{mmol} \mathrm{L}^{-1}$ indicate a negative energy balance. Based on values of BHB and NEFA, we can conclude that the lambs in this study have a satisfactory energy status.

\section{Conclusions}

Spelt (Triticum aestivum spp. Spelta L.) is an ancient wheat species with a higher resistance to harsh environmental influences than common wheat. Based on the results from the present research, it can be concluded that spelt is an appropriate ingredient in the diet of weaned lambs and can partially replace barley and oats with no negative effect on lambs' growth and the quality of lamb meat. Furthermore, given the results obtained in the present research, spelt could be a potentially suitable feed in organic lamb rearing.

Author Contributions: Conceptualization J.N. and Z.A.; methodology, J.N., Z.A., Z.S. and Ž.K.Š.; conducted the research J.N., Ž.K.Š., M.R., D.S. and V.S.; analyzed the data and wrote the manuscript J.N. All authors have read and agreed to the published version of the manuscript.

Funding: Funding's support in agriculture and rural development of Osijek-Baranja County, Croatia.

Data Availability Statement: The data presented in this study are available on request from the corresponding author.

Acknowledgments: The authors are grateful to Vinko and Slavko Sičaja who managed the flock.

Conflicts of Interest: The authors state that they have no conflict of interest. The funders had no role in the design of the study; in the collection, analyses, or interpretation of data; in the writing of the manuscript, or in the decision to publish the results. All authors have read and agreed to the published version of the manuscript.

\section{References}

1. FIBL-IFOAM. The World of Organic Agriculture. In Medienhaus Plump; FIO International: Rheinbreitbach, Germany, 2019; pp. 40-55. Available online: https:/ / www.google.com/search?client=firefox-b-d\&q=The+World+of+Organic+Agriculture+-+ Comisi $\%$ C3\%B3n+Interamericana+... (accessed on 29 December 2020).

2. Oates, L.; Cohen, M.; Braun, L. Characteristics and consumption patterns of Australian organic consumers. J. Sci. Food Agric. 2012, 92, 2782-2787. [CrossRef] [PubMed]

3. EUROSTAT. Organic Farming Retrieved 22/05/2019. 2019. Available online: https://ec.europa.eu/eurostat/data/database (accessed on 29 December 2020).

4. Croatian Ministry of Agriculture 2020. Available online: https://poljoprivreda.gov.hr/statistika-360/360 (accessed on 25 September 2020).

5. Magnusson, M.K.; Arvola, A.; Hursti, U.K.K.; Åberg, L.; Sjödén, P.O. Choice of organic foods is related to perceived consequences for human health and to environmentally friendly behavior. Appetite 2003, 40, 109-117. [CrossRef]

6. Wier, M.; Calverley, C. Market potential for organic foods in Europe. Br. Food J. 2002, 104, 45-62. [CrossRef]

7. Smith-Spangler, C.; Brandeau, M.L.; Hunter, G.E.; Bavinger, J.C.; Pearson, M.; Eschbach, P.J.; Sundaram, V.; Liu, H.; Schirmer, P.; Stave, C.; et al. Are organic foods safer or healthier than conventional alternatives? A systematic review. Ann. Intern. Med. 2012, 157, 348-366. [CrossRef]

8. Beane, T. Buying organic. J. Am. Vet. Med. 2013, 242, 1048.

9. Bonafaccia, G.; Galli, V.; Francisci, R.; Mair, V.; Skrabanja, V.; Kreft, I. Characteristics of spelt wheat products and nutritional value of spelt wheat-based bread. Food Chem. 2000, 68, 437-441. [CrossRef] 
10. Mlinar, R.; Ikić, I. BcVigor-novi kultivar ozimog pravog pira. Sjemenarstvo 2012, 29, 15-23.

11. Ruibal-Mendieta, N.L.; Delacroix, D.L.; Mignolet, E.; Pycke, J.M.; Marques, C.; Rozenberg, R.; Petitjean, G.; Habib-Jiwan, J.L.; Meurens, M. Spelt (Triticum aestivum ssp. spelta) as a source of breadmaking flours and bran naturally enriched in oleic acid and minerals but not phytic acid. J. Agric. Food Chem. 2005, 53, 2751-2759. [CrossRef] [PubMed]

12. Escarnot, E.; Jacquemin, J.M.; Agneessens, R.; Paquot, M. Comparative study of the content and profiles of macronutrients in spelt and wheat, a review. Biotechnol. Agron. Soc. Environ. 2012, 16, 243-256.

13. Wojtkowiak, K.; Stepien, A. Nutritive value of spelt (Triticum aestivum spp. spelta L.) as influenced by the foliar application of copper, zinc and manganese. Zemdirbyste 2015, 102, 389-396. [CrossRef]

14. Novoselec, J.; Klir, Ž.; Domaćinović, M.; Lončarić, Z.; Antunović, Z. Biofortification of feedstuffs with microelements in animal nutrition. Poljoprivreda (Osijek) 2018, 24, 25. [CrossRef]

15. Pearson, D.A. The Chemical Analysis of Foods; Curchill Livingstone: Edinburgh, UK, 1976; pp. 6-25.

16. Offor, I.F.; Ehiri, R.C.; Njoku, C.N. Proximate nutritional analysis and heavy metal composition of dried Moringa Oleifera leaves from Oshiri Onicha, L.G.A, Ebonyi State, Nigeria. J. Environ. Sci. Toxicol. Food Technol. 2014, 8, 57-62. [CrossRef]

17. European Union (EU): Council Regulation (EC). No. 834/2007 on Organic Production and Abeling of Organic Products with Regard to Organic Production, Labeling and Control. Official Journal of the EU, 2007. Available online: http:/ / eur-lex.europa.eu/ legal-content/EN/TXT/?uri=celex:32007R0834 (accessed on 17 October 2020).

18. CIE (Commission Internationale de l'Eclairage): Colorimetry, Official Recommendations of the International Commission on Illumination; Publication CIE No. 15 (E-1.3.1); Bureau Central dela CIE: Paris, France, 1976.

19. Sierra, I. Contributions to the study of the Belgian White_Landrace cross: Productive characters, carcass quality and meat quality. Rev. Inst. Econom. Prod. Ebro 1973, 16, 43-48.

20. Bonanno, A.; Tornambe, G.; Di Grigoli, A.; Genna, V.; Bellina, V.; Di Miceli, G.; Giambalvo, D. Effect of legume grains as a source of dietary protein on the quality of organic lamb meat. J. Sci. Food Agric. 2012, 92, 2870-2875. [CrossRef]

21. Antunović, Z.; Šperanda, M.; Novoselec, J.; Đidara, M.; Mioč, B.; Klir, Ž.; Samac, D. Blood metabolic profile and acid-base balance of dairy goats and their kids during lactation. Vet. Arh. 2017, 87, 43-55.

22. Držaić, V.; Mioč, B.; Živković, L.; Antunović, Z.; Bagarić, J.; Širić, I. Slaughter traits, carcass measures and meat quality of Merinolandschaf lambs in Croatia. J. Cent. Eur. Agric. 2018, 19, 278-294. [CrossRef]

23. Niznikowski, R.; Oprzadek, A.; Sweiatek, M.; Czub, G.; Glowacz, K.; Slezak, M. Slaughter value and meat quality of Polish Merino and Berrichon DuCher ram lambs in intensitive housing system. Acta Sci. Pol. Zootech. 2014, 13, 41-45.

24. Fiems, L.O.; De Boever, J.L.; Vanacker, J.M.; De Campeneere, S.; De Brabander, D.L. Spelt as an ingredient in concentrates for rearing calves. Livest. Sci. 2012, 150, 349-356. [CrossRef]

25. Early, D.M.; Provenza, F.D. Food flavor and nutritional characteristics alter dynamics of food preference in lambs. J. Anim. Sci. 1998, 76, 728-734. [CrossRef]

26. Ingalls, J.R.; Morgan, D.E.; Thomas, J.W.; Huffman, C.F. Nutritive value of spelt (Triticum Sativum Spelta) for dairy cattle. J. Dairy Sci. 1963, 46, 1085-1088. [CrossRef]

27. Rosenvold, K.; Andersen, H.J. Factors of significance for pork quality-A review. Meat Sci. 2003, 64, 219-237. [CrossRef]

28. Bertram, H.C.; Petersen, J.S.; Andersen, H.J. Relationship between RN- genotype and drip loss in meat from Danish pigs. Meat Sci. 2000, 56, 49-55. [CrossRef]

29. Oeckel, M.J.; Warnants, N.; Boucqué, C.V. Comparison of different methods for measuring water holding capacity and juiciness of pork versus on-line screening methods. Meat Sci. 1999, 51, 313-320. [CrossRef]

30. Toscas, P.J.; Shaw, F.D.; Beilken, S.L. Partial least squares (PLS) regression for the analysis of instrument measurements and sensory meat quality data. Meat Sci. 1999, 52, 173-178. [CrossRef]

31. Cheng, Q.; Sun, D.W. Factors affecting the water holding capacity of red meat products: A review of recent research advances. Crit. Rev. Food Sci. Nutr. 2008, 48, 137-159. [CrossRef]

32. Bendall, J.R.; Swatland, H.J. A review of the relationships of $\mathrm{pH}$ with physical aspects of pork quality. Meat Sci. 1988, 24, 85-126. [CrossRef]

33. Lawrie, R.A. Meat Science; Pergamon Press: New York, NY, USA, 1988; pp. 128-155.

34. Hopkins, D.L. Assessment of lamb meat colour. Meat Focus Int. 1996, 5, 400-401.

35. Khliji, S.; Van de Ven, R.; Lamb, T.A.; Lanza, M.; Hopkins, D.L. Relationship between consumer ranking of lamb colour and objective measures of colour. Meat Sci. 2010, 85, 224-229. [CrossRef] [PubMed]

36. Joy, M.; Ripoll, G.; Delfa, R. Effects of feeding system on carcass and non-carcass composition of Churra Tensina light lambs. Small Rumin. Res. 2008, 78, 123-133. [CrossRef]

37. Priolo, A.; Micol, D.; Agabriel, J.; Prache, S.; Dransfield, E. Effect of grass or concentrate feeding systems on lamb carcass and meat quality. Meat Sci. 2002, 62, 179-185. [CrossRef]

38. Priolo, A.; Micol, D.; Agabriel, J. Effects of grass feeding systems on ruminant meat colour and flavour. A review. Anim. Res. 2001, 50, 185-200. [CrossRef]

39. Ripoll, G.; Joy, M.; Muñoz, F.; Albertí, P. Meat and fat colour as a tool to trace grass-feeding systems in light lamb production. Meat Sci. 2008, 80, 239-248. [CrossRef]

40. Lepherd, M.L.; Canfield, P.J.; Hunt, G.B.; Bosward, K.L. Hematological, biochemical and selected acute phase protein reference intervals for weaned female Merino lambs. Aust. Vet. J. 2009, 87, 5-11. [CrossRef] [PubMed] 
41. Kaneko, J.J.; Harvey, J.W.; Bruss, M.L. (Eds.) Clinical Biochemistry of Domestic Animals, 6th ed.; Elsevier Academic Press: Amsterdam, The Netherlands, 2008; p. 931.

42. Antunovic, Z.; Novoselec, J.; Sencic, Đ.; Šperanda, M.; Steiner, Z.; Samac, D. Production traits and blood biochemical parameters in organic lamb production. In Proceedings of the 45th Croatian and 5th International Symposium on Agriculture, Opatija, Croatia, 15-19 February 2010; pp. 1014-1018.

43. Feitosa, F.L.F.; Mendes, L.C.N.; Peiró, J.R.; Cadioli, F.A.; Yanaka, R.; Bovino, F.; Féres, F.C.; Perri, S.H.V. Influência da faixa etária nos valores de enzimas hepáticas e de uréia e creatinina em bezerros Holandeses do nascimento até os 365 dias de vida. Ciência Veterinária Nos Trópicos 2007, 10, 54-61.

44. Mohri, M.; Sharifi, K.; Eidi, S. Hematology and serum biochemistry of Holstein dairy calves: Age related changes and comparison with blood composition in adults. Res. Vet. Sci. 2007, 83, 30-39. [CrossRef] [PubMed]

45. Cruz, R.E.S.; Rocha, F.M.; Sena, C.V.B.; Noleto, P.G.; Guimarães, E.C.; Galo, J.A.; Mundim, A.V. Effects of age and sex on blood biochemistry of Dorper lambs. Semin. Cienc. Agrar. 2017, 38, 3085-3094. [CrossRef]

46. Russell, K.E.; Roussel, A.J. Evaluation of the ruminant serum chemistry profile. Vet. Clin. N. Am. Food Anim. 2007, 23, 403-426. [CrossRef] [PubMed]

47. Bórnez, R.; Linares, M.B.; Vergara, H. Haematological, hormonal and biochemical blood parameters in lamb: Effect of age and blood sampling time. Livest. Sci. 2009, 121, 200-206. [CrossRef]

48. Braun, J.P.; Trumel, C.; Bézille, P. Clinical biochemistry in sheep: A selected review. Small Rumin. Res. 2010, 92, 10-18. [CrossRef]

49. Frutos, P.; Raso, M.; Hervás, G.; Mantecón, Á.R.; Pérez, V.; Giráldez, F.J. Is there any detrimental effect when a chestnut hydrolysable tannin extract is included in the diet of finishing lambs? Anim. Res. 2004, 53, 127-136. [CrossRef]

50. Kaneko, J.J.; Harvey, J.W.; Bruss, M.L. (Eds.) Clinical Biochemistry of Domestic Animals, 5th ed.; Academic Press: San Diego, CA, USA, 1997; p. 158. [CrossRef]

51. González, F.H.D.; Scheffer, J.F.S. Perfil sanguíneo: Ferramenta de análise clínica, metabólica e nutricional. In Avaliação metabóliconutricional de vacas leiteiras por meio de fluídos corporais (sangue, leite e urina). In Anais do $29^{\circ}$ Congresso Brasileiro de Medicina Veterinária; Gramado, RS 1; UFRGS: Porto Alegre, Brazil, 2003; pp. 5-17.

52. Kaneto, F.M.; Coelho, C.S.; Leal, M.L.R.; Lisboa, J.A.N. and Benesi, F.J. Blood glucose and Anion Gap of healthy female Holstein calves during the first month of life. Ars Vet. 2004, 20, 291-298.

53. Kritchevsky, D.; Tepper, S.A.; Czarnecki, S.K.; Klurfeld, D.M. Atherogenicity of animal and vegetable protein: Influence of the lysine to arginine ratio. Atherosclerosis 1982, 41, 429-431. [CrossRef]

54. Kurowska, E.M.; Carroll, K.K. Hypercholesterolemic responses in rabbits to selected groups of dietary essential amino acids. J. Nutr. 1994, 124, 364-370. [CrossRef]

55. Santos, R.P.; Sousa, L.F.; Sousa, J.T.L.; Andrade, M.E.B.; Macedo Júnior, G.L.; Silva, S.P. Parâmetros sanguíneos de cordeiros em crescimento filhos de ovelhas suplementadas com níveis crescentes de propilenoglicol. Revista Brasileira de Ciências Agrárias (Agrária) 2015, 10, 473-478. [CrossRef]

56. Sampelayo, M.S.; Lupiani, M.J.; Guerrero, J.E.; Boza, J. A comparison of different metabolic types between goat kids and lambs: Key blood constituents at different times in the first two months after birth. Small Rumin. Res. 1998, 31, 29-35. [CrossRef]

57. Baranowski, P.; Baranow-Baranowski, S.; Klata, W. Some haematological and biochemical serum and bone tissu indices of lambs derived from ewes fed on vitamin- and mineral-vitamin supplements during pregnancy. Bull. Vet. Inst. Pulawy. 2000, 44, 204-214.

58. Peixoto de Oliveira, L.A.; Osório, M.T.M. Perfil metabólico proteico e energético na avaliação do desempenho reprodutivo em ruminantes. Revista Brasileira de Agrociência 2007, 13, 299-304.

59. Shaffer, L.; Roussel, J.D.; Koonce, K.L. Effects of age, temperature-season, and breed on blood characteristics of dairy cattle. J. Dairy Sci. 1981, 64, 62-70. [CrossRef]

60. de Souza, D.F.; Reijers, T.S.S.S.; Gilaverte, S.; da Cruz, T.A.; Hentz, F.; Castilhos, B.D.Q.; Dittrich, R.L.; Monteiro, A.L.G. Dynamics of biochemical parameters in lambs during the first four months of life. Rev. Bras. Zootec. 2020, 49. [CrossRef] 